\title{
PENGARUH MODEL PEMBELAJARAN KOOPERATIF TIPE GROUP INVESTIGATION TERHADAP HASIL BELAJAR SISWA
}

\author{
Ando Hutagalung dan Usler Simarmata \\ andohutagalung76@gmail.com \\ Jurusan Fisika FMIPA Universitas Negeri Medan \\ Jalan Willem Iskandar Pasar V Medan, 20221
}

\begin{abstract}
The purpose of this study was to determine the effect of cooperative learning model type Group Investigation (GI) on learning outcomes of students in the subject matter of temperature and heat in SMP PGRI 4 Medan. This type of research is quasi-experimental. The population of this entire class VIII SMP PGRI 4 Medan much as three classes. The sample in this study was taken as a random sampling of two classes. The instrument used to determine student learning outcomes in the material temperature and heat in the form of multiple-choice questions numbered 20 and the observation sheet. The results obtained by testing hypotheses that there is a significant relationship between the use of cooperative learning model GI on student learning outcomes.
\end{abstract}

\section{Keywords: Cooperative learning model group investigation, learning outcomes.}

\section{PENDAHULUAN}

Pendidikan merupakan sarana penting dalam meningkatkan kualitas sumber daya manusia (SDM). Dewasa ini, peningkatan kualitas SDM jauh lebih mendesak untuk segera direalisasikan terutama dalam menghadapi era persaingan global. Oleh karena itu, peningkatan kualitas SDM sejak dini merupakan hal penting yang harus dipikirkan secara sungguh-sungguh. Upaya yang tepat untuk menyiapkan SDM yang berkualitas dan satu-satunya wadah yang dapat dipandang sebagai alat untuk membangun SDM yang bermutu tinggi adalah pendidikan sekolah.

Sekolah adalah salah satu intuisi dalam pengembangan SDM. Pendidikan sekolah adalah pendidikan yang diperoleh seseorang di sekolah secara teratur, sistematis, bertingkat dan mendekati syaratsyarat yang jelas dan ketat mulai dari taman kanak-kanak sampai perguruan tinggi. Sekolah idealnya harus mampu melakukan proses edukasi dan sosialisasi. Dengan kata lain, sekolah yang bermutu adalah sekolah yang mampu berperan sebagai proses edukasi (proses pendidikan yang menekankan pada kegiatan mendidik dan mengajar), proses sosialisasi (proses bermasyarakat terutama bagi anak didik), dan wadah proses transformasi (proses perubahan tingkah laku ke arah yang lebih baik/lebih maju) .

Salah satu mata pelajaran yang diajarkan di sekolah adalah Fisika. Fisika merupakan ilmu pengetahuan yang mempelajari 
tentang peristiwa dan fenomena alam. Oleh karena itu, pelajaran Fisika termasuk salah satu pelajaran yang cukup menarik karena langsung berkaitan dengan kejadian yang nyata dan juga dapat diaplikasikan dalam kehidupan sehari-hari.

Kenyataannya pelajaran Fisika termasuk salah satu mata pelajaran yang memiliki nilai terendah. Hal ini disebabkan oleh banyaknya siswa yang kurang memahami pelajaran Fisika karena menurut mereka pelajaran Fisika merupakan pelajaran yang sulit dipahami, khususnya jika dihadapkan dengan rumus-rumus dan perhitungan yang menjenuhkan siswa. Hal yang sama penulis temukan di SMP PGRI 4 Medan melalui wawancara terhadap beberapa guru mata pelajaran Fisika. Melalui wawancara yang penulis laksanakan, diperoleh data bahwa hasil belajar Fisika siswa pada umumnya masih rendah yaitu ratarata 65 sementara Kriteria Ketuntasan Minimal (KKM) yang seharusnya dicapai adalah 70 . Khususnya pada materi pokok Tekanan, hasil belajar siswa hanya mendapat rata-rata 60 . Sehingga dapat dikatakan nilai rata-rata siswa belum mencapai kriteria yang diharapkan. Selain itu, penulis juga memberikan angket persepsi terhadap pelajaran fisika di kelas VIII. Dari hasil angket tersebut diperoleh kesimpulan bahwa mereka kurang memahami pelajaran Fisika disebabkan karena materi Fisika banyak menggunakan rumus dan perhitungan sehingga siswa cenderung pasif dalam keterlibatan proses belajar mengajar dan jarang bertanya kepada guru apabila ada materi pelajaran yang kurang dimengerti. Selain itu, di sekolah tersebut kurang optimal dalam menggunakan sarana prasarana.

Hal lain yang menjadi penyebab rendahnya hasil belajar ini, salah satunya adalah metode atau model pembelajaran yang digunakan oleh guru. Berdasarkan pengamatan dilapangan terlihat bahwa guru dalam mengajar Fisika menggunakan model pembelajaran konvensional, yaitu Guru menekankan kepada siswa hafalan dan ingatan saja sehingga mengakibatkan kebiasaan siswa secara tidak langsung dalam menyelesaikan soal hanya mengandalkan hafalan saja. Proses pembelajaran yang memiliki kecenderungan pada metode tertentu (konvensional), yaitu metode ceramah dan tidak memperhatikan tingkat pemahaman siswa terhadap informasi akan mengakibatkan kebosanan pada siswa, seperti yang disampaikan Djamarah (2006) menyatakan "Waktu guru mengajar bila hanya menggunakan salah satu metode maka akan membosankan, siswa tidak tertarik perhatiannya pada pelajaran".

Model pembelajaran yang dapat mengurangi kebosanan dan kejenuhan pada siswa adalah model pembelajaran yang memberikan kesempatan kepada anak didik untuk bekerja sama dengan sesama siswa dalam tugas-tugas yang terstruktur, atau disebut sebagai sistem "pembelajaran gotongroyong" atau cooperative learning (Lie, 2008). Cooperative learning merupakan sebuah kelompok strategi pengajaran yang melibatkan siswa bekerja secara berkolaborasi untuk mencapai tujuan bersama. Tujuan utama dalam penerapan model pembelajaran cooperative learning adalah agar peserta didik 
dapat belajar secara berkelompok bersama teman-temannya dengan cara saling menghargai pendapat dan memberikan kesempatan kepada orang lain untuk mengemukakan gagasannya dengan menyampaikan pendapat mereka secara berkelompok (Isjoni, 2009).

Model pembelajaran kooperatif terdiri dari beberapa jenis, salah satunya adalah model pembelajaran kooperatif tipe GI. Model pembelajaran kooperatif tipe GI adalah sebuah model yang tidak mengharuskan siswa menghafal fakta, rumus-rumus tetapi sebuah model yang membimbing para siswa mengidentifikasi topik, merencanakan investigasi dalam kelompok, melaksanakan penyelidikan, melaporkan, dan mempresentasikan hasil penyelidikannya.

Penelitian ini menerapkan model pembelajaran kooperatif tipe GI. Tujuan penelitian ini adalah untuk mengetahui ada tidaknya perbedaan akibat pengaruh model pembelajaran kooperatif tipe GI terhadap hasil belajar dan aktivitas siswa di kelas VIII SMP PGRI 4 Medan.

\section{METODE PENELITIAN}

Penelitian ini dilaksanakan mulai bulan Maret 2014 sampai Juni 2014 di SMP PGRI 4 MEDAN semester II tahun ajaran 2013/2014. Populasi penelitian ini adalah seluruh SMP PGRI 4 Medan semester II tahun ajaran 2013/2014.

Sampel penelitian terdiri dari dua kelas yaitu kelas eksperimen dan kelas kontrol. Kelas eksperimen berjumlah 30 orang siswa terdiri dari 14 laki-laki dan 16 orang perempuan, sedangkan kelas kontrol berjumlah 30 orang terdiri dari 9 laki-laki dan 21 perempuan. Sampel diambil dari populasi dengan cara cluster random sampling. Kelas ekperimen diajarkan dengan model pembelajaran kooperatif tipe GI dan kelas kontrol diajarkan dengan model pembelajaran konvensional. Untuk mengetahui hasil belajar fisika siswa dilakukan dengan memberikan tes pada kedua kelas sebelum dan sesudah diberi perlakuan. Rancangan penelitian ini ditunjukkan pada Tabel 1.

Tabel 1. Pretest-Postest Design

\begin{tabular}{|l|c|c|c|}
\hline Kelas & Pretes & Perlakuan & Postes \\
\hline Eksperimen & $\mathrm{T}_{1}$ & $X_{1}$ & $\mathrm{~T}_{2}$ \\
Kontrol & $\mathrm{T}_{1}$ & $X_{2}$ & $\mathrm{~T}_{2}$ \\
\hline
\end{tabular}

Keterangan :

$\mathrm{X}_{1}=$ Pembelajaran dengan model kooperatif tipe GI

$\mathrm{X}_{2}=$ Pembelajaran dengan pembelajaran konvensional

$\mathrm{T}_{1}=$ Pemberian pretes

$\mathrm{T}_{2}=$ Pemberian postes

Instrumen yang digunakan dalam pengambilan data ini adalah tes berbentuk pilihan berganda. Tes hasil belajar ini digunakan untuk mengetahui kemampuan siswa pada tingkat kognitif. Perincian kisi-kisi tes hasil belajar siswa ditunjukkan pada Tabel 2.

Tabel 2. Perincian Kisi-Kisi Tes Hasil Belajar Siswa

\begin{tabular}{|c|c|c|c|c|c|c|c|c|}
\hline \multirow[b]{2}{*}{ NO } & \multirow{2}{*}{$\begin{array}{c}\text { Sub } \\
\text { Materi } \\
\text { Pokok }\end{array}$} & \multicolumn{6}{|c|}{ Klasifikasi } & \multirow{2}{*}{$\begin{array}{l}\text { Jlh } \\
\text { Soal }\end{array}$} \\
\hline & & $\mathrm{C}_{1}$ & $\mathrm{C}_{2}$ & $\mathrm{C}_{3}$ & $\mathrm{C}_{4}$ & $\mathrm{C}_{5}$ & $\mathrm{C}_{6}$ & \\
\hline 1 & $\begin{array}{l}\text { Pengertia } \\
\mathrm{n} \\
\text { Tekanan }\end{array}$ & $\begin{array}{l}1, \\
2\end{array}$ & & & 5 & & & 3 \\
\hline 2 & $\begin{array}{l}\text { Tekanan } \\
\text { pada Zat } \\
\text { Padat }\end{array}$ & & 3 & & & 16 & & 2 \\
\hline 3 & $\begin{array}{l}\text { Tekanan } \\
\text { pada Zat } \\
\text { Cair }\end{array}$ & & $\begin{array}{l}6, \\
11 \\
18\end{array}$ & 19 & $\begin{array}{l}7, \\
10, \\
15\end{array}$ & $\begin{array}{l}8, \\
14, \\
17\end{array}$ & 9 & 11 \\
\hline 4 & $\begin{array}{l}\text { Tekanan } \\
\text { Udara }\end{array}$ & & & $\begin{array}{l}12, \\
13\end{array}$ & $\begin{array}{l}4, \\
20\end{array}$ & & & 4 \\
\hline \multicolumn{2}{|c|}{ Jumlah Soal } & 2 & 4 & 3 & 6 & 4 & 1 & 20 \\
\hline
\end{tabular}


Data yang diperoleh ditabulasikan kemudian dicari rataratanya. Sebelum dilakukan penganalisisan data, terlebih dahulu ditentukan skor masing-masing kelompok sampel lalu dilakukan pengolahan data dengan langkahlangkah sebagai berikut: a) Menghitung nilai rata-rata dan simpangan bak, b) Uji normalitas, c) Uji homogenitas, d) Pengujian hipotesis (Sudjana, 2005).

Uji normalitas dilakukan untuk mengetahui apakah populasi berdistribusi normal atau tidak. Langkah awal yang dilakukan adalah menentukan nilai rata-rata sebelum dilakukan uji normalitas.

Uji homogenitas bertujuan untuk mengetahui apakah data mempunyai varians yang homogen atau tidak.

Uji hipotesis dua pihak menggunakan uji $t$ untuk data pretes. Uji t dua pihak digunakan untuk melihat kemampuan awal siswa pada kedua kelompok sampel. Uji hipotesis satu pihak menggunakan uji $t$ untuk data postes. Uji t satu pihak digunakan untuk mengetahui hasil belajar siswa dari suatu perlakuan yaitu model pembelajaran GI.

Sintaks model pembelajaran kooperatif tipe GI diadopsi dari (Trianto,2010) seperti ditunjukkan pada Tabel 3 berikut:
Tabel 3. Sintaks Model Pembelajaran Kooperatif tipe GI

\begin{tabular}{|c|c|}
\hline Fase & Aktivitas guru \\
\hline $\begin{array}{l}\text { Fase-1 } \\
\text { Pemilihan } \\
\text { Topik. }\end{array}$ & $\begin{array}{l}\text { Guru } \\
\text { menetapkan } \\
\text { masalah yang } \\
\text { akan di } \\
\text { diskusikan oleh } \\
\text { para siswa. } \\
\text { Membagi siswa } \\
\text { ke dalam } \\
\text { kelompok secara } \\
\text { heterogen }\end{array}$ \\
\hline $\begin{array}{l}\text { Fase-2 } \\
\text { Perencanaan } \\
\text { Kooperatif }\end{array}$ & $\begin{array}{l}\text { Guru menjelaskan } \\
\text { prosedur } \\
\text { pembelajaran } \\
\text { dan tugas untuk } \\
\text { para siswa. } \\
\text { Guru } \\
\text { membagikan } \\
\text { LKS serta } \\
\text { menugaskan } \\
\text { siswa untuk } \\
\text { melakukan } \\
\text { investigasi } \\
\text { (penyelidikan). }\end{array}$ \\
\hline $\begin{array}{l}\text { Fase-3 } \\
\text { Implementasi. }\end{array}$ & $\begin{array}{l}\text { Guru mengikuti } \\
\text { kemajuan } \\
\text { tiap kelompok } \\
\text { dan } \\
\text { menawarkan } \\
\text { bantuan bila } \\
\text { diperlukan. }\end{array}$ \\
\hline $\begin{array}{l}\text { Fase-4 } \\
\text { Analisis dan } \\
\text { sintesis. }\end{array}$ & $\begin{array}{l}\text { Guru memantau } \\
\text { siswa dalam } \\
\text { membuat bahan } \\
\text { presentasi }\end{array}$ \\
\hline $\begin{array}{l}\text { Fase }-5 \\
\text { Presentasi } \\
\text { hasil }\end{array}$ & $\begin{array}{l}\text { Guru } \\
\text { mengkoordinasi } \\
\text { siswa dalam } \\
\text { melakukan } \\
\text { presentasi }\end{array}$ \\
\hline $\begin{array}{l}\text { Fase-6 } \\
\text { Evalusi }\end{array}$ & $\begin{array}{l}\text { Guru bersama } \\
\text { dengan siswa } \\
\text { merangkum } \\
\text { materi pelajaran }\end{array}$ \\
\hline
\end{tabular}




\section{HASIL DAN PEMBAHASAN}

\section{a. Hasil Penelitian}

Adapun hasil penelitian ini adalah nilai rata-rata pretes kelas eksperimen sebesar 43,16 dan nilai rata-rata pretes kelas kontrol sebesar 41,33. Data nilai pretes kelas eksperimen dan kelas kontrol ditunjukkan pada tabel 4 .

Tabel 4. Data Nilai Pretes Kelas

Eksperimen dan Kelas Kontrol

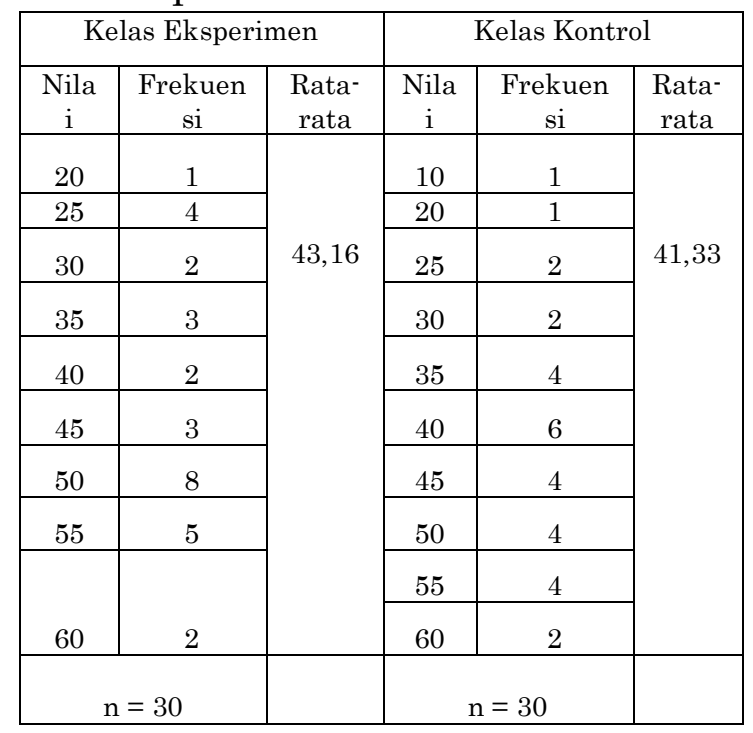

Berdasarkan Tabel 4 yaitu pada kelas eksperimen memiliki rata-rata pretes sebesar 43,16 sedangkan pada kelas kontrol memiliki ratarata pretes sebesar 41,33.

Tabel 4 di atas menunjukkan bahwa nilai pretes pada kelas eksperimen dan kelas kontrol tidak jauh berbeda, artinya kedua kelas mempunyai kemampuan awal yang hampir sama dan perolehan nilai kedua kelas merata.

Kemudian kedua kelas sampel diberikan perlakuan yang berbeda, pada kelas eksperimen diberikan perlakuan dengan menerapkan model pembelajaran kooperatif tipe GI sedangkan pada kelas kontrol diberikan perlakuan dengan menerapkan

pembelajaran

konvensional. Setelah kedua kelas diberikan perlakuan yang berbeda, kedua kelas selanjutnya diberikan postes dengan soal yang sama seperti soal pretes. Hasil yang diperoleh adalah, nilai rata-rata postes kelas eksperimen setelah diterapkan pembelajaran dengan menggunakan model kooperatif tipe GI adalah: 75,66. Sedangkan pada kelas kontrol setelah diterapkan pembelajan konvensional diperoleh nilai rata-rata postes sebesar: 65,00. Nilai postes siswa kedua kelas tersebut dapat dilihat dalam Tabel 5 berikut:

Tabel 5. Data Nilai Pretes Kelas

Eksperimen dan Kelas Kontrol

\begin{tabular}{|c|c|c|c|c|c|}
\hline \multicolumn{3}{|c|}{ Kelas Eksperimen } & \multicolumn{3}{|c|}{ Kelas Kontrol } \\
\hline Nilai & Frekuensi & $\begin{array}{l}\text { Rata- }^{-} \\
\text {rata }\end{array}$ & Nilai & $\begin{array}{c}\text { Frekuen } \\
\text { si }\end{array}$ & $\begin{array}{l}\text { Rata } \\
\text {-rata }\end{array}$ \\
\hline 65 & 6 & \multirow{9}{*}{75,66} & 50 & 6 & \multirow{9}{*}{65} \\
\hline 70 & 7 & & 55 & 5 & \\
\hline 75 & 5 & & 60 & 3 & \\
\hline 80 & 4 & & 65 & 3 & \\
\hline 85 & 5 & & 70 & 3 & \\
\hline \multirow[t]{3}{*}{90} & 3 & & 75 & 3 & \\
\hline & & & 80 & 6 & \\
\hline & & & 85 & 1 & \\
\hline \multicolumn{2}{|c|}{$\mathrm{n}=30$} & & \multicolumn{2}{|c|}{$\mathrm{n}=30$} & \\
\hline
\end{tabular}

Berdasarkan

Tabel

5 menunjukkan bahwa hasil belajar di kelas eksperimen lebih baik dari pada di kelas kontrol. Hal ini dapat dilihat dari hasil perolehan postes siswa di kelas eksperimen umumnya lebih tinggi dari kelas kontrol.

Perhitungan uji t nilai ratarata postes kelas eksperimen dan kelas kontrol, diperoleh $t_{\text {hitung }}=4,11$ $>t_{\text {tabel }}=1,69$ maka $H_{0}$ ditolak, sehingga diperoleh kesimpulan bahwa ada pengaruh yang signifikan model pembelajaran kooperatif tipe GI terhadap hasil 
belajar siswa pada materi pokok Tekanan di kelas VIII SMP PGRI 4 Medan T.P. 2013/2014. Ringkasan Perhitungan Uji Hipotesis ditunjukkan pada tabel 6 .

Tabel 6. Ringkasan Perhitungan Uji Hipotesis Kemampuan Postes

\begin{tabular}{|c|c|c|c|c|c|}
\hline No & Data Kelas & $\begin{array}{l}\text { Nilai } \\
\text { Rata- } \\
\text { rata }\end{array}$ & $\begin{array}{c}\mathrm{t} \\
\text { hitung }\end{array}$ & $\begin{array}{c}\mathrm{t} \\
\text { tabel }\end{array}$ & Kesimpulan \\
\hline 1 & $\begin{array}{l}\text { Postes } \\
\text { Eksperimen }\end{array}$ & 75,66 & \multirow[b]{2}{*}{4,11} & \multirow[b]{2}{*}{1,69} & \multirow{2}{*}{$\begin{array}{c}\text { Ada } \\
\text { pengaruh } \\
\text { terhadap } \\
\text { hasil } \\
\text { belajar }\end{array}$} \\
\hline 2 & $\begin{array}{l}\text { Postes } \\
\text { Kontrol }\end{array}$ & 65 & & & \\
\hline
\end{tabular}

Berdasarkan Tabel 6 menunjukkan bahwa ada pengaruh model pembelajaran kooperatif tipe GI terhadap hasil belajar siswa di kelas eksperimen. Selain hasil belajar yang mengalami peningkatan juga aktivitas belajar siswa yaitu pada pertemuan I ratarata aktivitas siswa diperoleh sebesar 56,08. Pada pertemuan II diperoleh peningkatan terhadap aktivitas siswa dengan nilai ratarata 61,11. Pada pertemuan III diperoleh peningkatan yang positif terhadap aktivitas siswa dengan nilai rata-rata 74,48. Sehingga diperoleh rata-rata nilai keseluruhan aktivitas belajar siswa adalah 63,89 termasuk dalam kategori aktif sehingga hipotesis alternatif yang telah diajukan peneliti diterima. Hal ini juga didukung dengan hasil penelitian terdahulu, yang menyatakan bahwa ada pengaruh yang positif dari model pembelajaran kooperatif tipe GI terhadap aktivitas dan hasil belajar.

\section{b. Pembahasan}

Selama pelaksanaan penelitian ini diperoleh bahwa model pembelajaran kooperatif tipe GI lebih menguntungkan karena model ini memang didesain untuk membuat siswa lebih aktif (student centered learning) dalam menggali, menemukan, menganalisis, mengevaluasi konsep terhadap materi pelajaran yang sedang dipelajari. Seperti yang diungkapkan oleh (Slavin, 2005) "Dalam implementasi model pembelajaran kooperatif tipe GI, guru membagi siswa menjadi kelompokkelompok dengan anggota 5-6 siswa yang heterogen. Kelompok disini dapat dibentuk dengan mempertimbangkan keakraban persahabatan atau minat yang sama dalam topik tertentu". Berarti siswa harus aktif didalam pembelajaran GI ini. Model pembelajaran kooperatif tipe GI merupakan model yang efisien untuk mempresentasikan informasi yang telah terorganisir dari suatu topik yang luas menjadi topik yang lebih mudah dipahami untuk setiap tingkatan perkembangan konsep (Rusman,2012).

Walaupun penggunaan model pembelajaran kooperatif tipe GI dapat meningkatkan hasil belajar dan aktivitas siswa, akan tetapi selama pembelajaran masih ada kendala yang dihadapi, yaitu waktu yang diperlukan untuk tiap-tiap fase kurang sesuai dengan skenario waktu yang telah direncanakan dalam Rencana Pelakasanaan Pembelajaran (RPP). Oleh karena itu, untuk peneliti selanjutnya supaya memberikan pengawasan yang lebih dengan dibantu oleh salah satu guru di sekolah yang menjadi tempat penelitian dan waktu yang yang direncanakan dalam RPP supaya lebih diperhatikan khususnya waktu dalam kegiatan melakukan percobaan karena siswa-siswa SMA 
ataupun SMP pada umumnya jarang melakukan percobaan sehingga pada saat melakukan percobaan dibutuhkan waktu yang lebih lama. Selain waktu masalah yang dihadapi peneliti adalah masih ada sebagian siswa yang kurang aktif dalam proses pembelajaran.

\section{KESIMPULAN}

Kesimpulan penelitian ini didasarkan pada temuan-temuan dari data-data hasil penelitian, sistematika sajiannya dilakukan dengan memperhatikan tujuan penelitian yang telah dirumuskan. Adapun kesimpulan yang diperoleh antara lain :

1. Hasil belajar siswa yang diberi pembelajaran dengan menggunakan model pembelajaran kooperatif tipe GI pada materi pokok Tekanan di kelas VIII SMP PGRI 4 Medan secara individu 16 orang tuntas yaitu 53\%, dan secara kelas tergolong tuntas. Sedangkan hasil belajar siswa yang diberi pembelajaran dengan menggunakan model pembelajaran konvensional pada materi pokok Tekanan di kelas VIII SMP PGRI 4 Medan secara individu 10 orang tuntas yaitu $33 \%$ dan secara kelas tergolong tidak tuntas. Maka dapat disimpulkan ada perbedaan akibat pengaruh penggunaan model pembelajaran kooperatif tipe GI pada materi pokok
Tekanan di kelas VIII SMP PGRI 4 Medan.

2. Aktivitas siswa selama mengikuti pembelajaran dengan menggunakan model pembelajaran kooperatif tipe GI untuk materi pokok Tekanan di kelas VIII SMP PGRI 4 Medan diperoleh rata-rata skor aktivitas siswa pada ketiga pertemuan mencapai 74,16 dengan kategori nilai $\mathrm{B}$.

\section{DAFTAR PUSTAKA}

Djamarah. 2006. Strategi Belajar Mengajar. Rineka Cipta; Jakarta.

Isjoni. 2009. Cooperative Learning. Alfabeta; Bandung

Lie,A.,2008. Cooperative Learning, Grafindo; Jakarta.

Rusman, 2012. Model-Model Pembelajaran. Raja

Grafindo Persada; Jakarta.

Slameto. 2010. Belajar dan FaktorFaktor yang

Mempengaruhinya Cetakan Kelima. PT Rineka Cipta; Jakarta.

Slavin,R. 2005. Cooperative Learning Edisi Kedua. Nusa Media; Bandung.

Sudjana. 2005. Metoda Statistika. Tarsito; Bandung

Trianto. 2010. Mendesain Model Pembelajaran Inovatif Progresif. Penerbit Kencana, ; Jakarta. 